\title{
HSPA5 Gene
}

National Cancer Institute

\section{Source}

National Cancer Institute. HSPA5 Gene. NCI Thesaurus. Code C48837.

This gene is involved in cellular signal transduction. 